\title{
IBTIDA
}

Jurnal Kajian Pendidikan Dasar

Vol. 1 No 1, Tahun 2021

\section{PENGARUH MOTIVASI, GAYA BELAJAR, DAN SUASANA RELIGIUS \\ TERHADAP PRESTASI BELAJAR PESERTA DIDIK DI MADRASAH IBTIDAIYAH NEGERI 3 PURWOREJO}

\author{
Purwanto
(MI Imam Puro, Purworejo) \\ Suharti \\ (MTs N 8 Kebumen) \\ hartimarwan@yahoo.com \\ Zakiyah \\ (Kankemenag Purworejo) \\ zakiyahmakmun@yahoo.com
}

\begin{abstract}
ABSTRAK
Penelitian ini didasari oleh pentingnya prestasi beelajar peserta didik.Sehubungan dengan hal tersebut, penelitian ini bertujuan untuk mengetahui Pengaruh Motivasi, Gaya Belajar, dan Suasana Religius terhadap Prestasi Belajar Peserta Didik di MIN 3 Purworejo. Penelitian ini merupakan penelitian kuantitatif. Populasi penelitian ini adalah seluruh peserta didik di MIN 3 Purworejo, sedangkan sampel penelitian yaitu peserta didik kelas VI di MIN 3 Purworejo yang berjumlah40 orang.Pengumpulan data menggunakan angket, dan analisis data menggunakan teknik analisis regresi sederhana dan regresi ganda. Penelitian ini menghasilkan kesimpulan sebagai berikut. (1) Motivasimemiliki pengaruh yang positif dan signifikan terhadap prestasi belajar peserta didik di MIN 3 Purworejo, terbukti dari nilai Sig = $0,038<\alpha=0,05$. Adapun nilai koefisien korelasi $\left(\mathrm{r}^{2}\right)=0,108$ atau berkontribusi sebesar $10,8 \%$. (2) Gaya belajar memiliki pengaruh yang positif dan signifikan terhadap prestasi belajar peserta didik di MIN 3 Purworejo, terbukti dari nilai Sig $=0,017<\alpha=0,05$. Adapun nilai koefisien korelasi $\left(\mathrm{r}^{2}\right)=0,141$ atau berkontribusi sebesar $14,1 \%$. (3) Suasana religius memiliki pengaruh yang tidak signifikan terhadap prestasi belajar peserta didik di MIN 3 Purworejo, terbukti dari nilai Sig $=0,000<\alpha=0,05$. Adapun nilaikoefisien korelasi $\left(\mathrm{r}^{2}\right)=$ 0,000 atau berkontribusi sebesar $00,0 \%$. (4) Motivasi, gaya belajar, dan suasana religius secara bersama-sama memiliki pengaruh yang positif dan signifikan terhadap prestasi belajar peserta didik di MIN 3 Purworejo, terbukti dari nilai Sig $=0,045<\alpha=0,05$. Adapun nilaikoefisien korelasi $\left(\mathrm{R}^{2}\right)=0,198$ atau berkontribusi sebesar $19,8 \%$.
\end{abstract}

Kata kunci: motivasi, gaya belajar, suasana religius, dan prestasi belajar peserta didik.

\section{PENDAHULUAN}

Pendidikan merupakan salah satu pilar kesejahteraan bangsa. Pendidikan merupakan satu satunya cara mengubah potensi sumber daya manusia menjadi human capital. Banyak pengertian pendidikan yang diambil oleh para ahli akan tetapi penulis cukup mengambil pengertian diatas.

Sedangkan pengertian pendidikan menurut perspektif Islam dan merujuk beberapa istilah yaitu al tarbiyah, al ta'dib.Al ta'lim. Dari 3 istilah tersebut yang popular digunakan 
dalam menyebutkan praktik pendiidkan Islam adalah terminologyal tarbiyah, seperrti penggunaan istilah at tarbiyah al islamiyah yang berarti pendidikan Islam. Pendidikan islam sesungguhnya menghendaki terbentuknya manusia yang berkepribadian muslim yang semua aspek aspek kehidupannya berlandaskan kepada ajaran Islam dan seluruh aktivitasnya diyakini sbagai ibadah dalam rangka pengabdian kepada Allah swt dan penyerahan kepada dirinya. $^{1}$

Lembaga menurut kamus besar bahasa Indonesia adalah bakal dari sesuatu, asal mula yang akan menjadi sesuatu, bakal, bentuk, wujud, rupa, acuan, ikatan, badan atau organisasi yang mmepunyai tujuan jelas terutama dalam bidang keilmuwan. Menurut ensklopedia Indonesia, lembaga pendidikan yaitu suatu wadah pendidikan yang dikelola demi mencapai hasil pendidikan yang diinginkan. Dari uraian diatas maka lembaga pendidikan islam adalah suatu wadah atau tempat berlangsungnya proses pendidikan Islam, lembaga ini mengandung konkrit berupa sarana dan prasarana dan juga penegrtian abstrak dengana danya norma norma dan peraturan peraturan tertentu serta pertanggungjawaban pendidikan itu sendiri.

Menurut Kihajar Dewantara penyelengara lembaga pendidikan memfokuskan dengan istilah "tricentra" yang meruapakan tempat pergaulan anak didik sebagai pusat pendidikan yang amat penting baginya. "Tricentra" ialah alam keluarga yang membetuk lembaga pendidikan keluarga, alam perguruan yang membentuk lembaga pendidikan sekolah dan alam pemuda yang membentuk lembaga masyarkat. Dalam agama islam lembaga pendidikan dibagi menjadi 3 yaitu lembaga keluarga, Masjid dan pondok pesantren serta madrasah.

Madrasah sebagai lembaga pendidikan Islam muncul dari penduduk "Nisapur" tetapi tersiarnya melalui menteri Saljuqi yang bernama "Nizam Am Mulk" yang mendirikan madrasah Nizomiyah. Selanjutnya Gibb dan krames menuturkan bahwa pendiri madrasah terbesar setelah Nizam Al Mulk adalah Shalahuddin Al Ayyuni. Kehadiran madrasah sebagai lembaga pendidikan Islam setidak-tidaknya mempunyai 4 latar belakang yaitu: (1) Sebagai manivestasi dan realisasi pembaharu sistem pendidikan Islam; (2) Usaha penyempurnaan terhadap sistem pesantren kearah suatu pendidikan yang lebih memungkinkan lulusannya memperoleh kesempatan yang sama dengan sekolah umum; (3) Adanya sikap mental sementara golongan umat islam. Khususnya santri yang terpaku pada barat sebagai sistem pendidikan mereka; dan (4) Sebagai upaya untuk menjembatani antar asistem pendidikan tradisonal yang dilakukan pesantren dan sistem pendidikan modern dari hasil akulturasi.

\footnotetext{
${ }^{1}$ Imam Machali \& Ara Hidayat. Pengelolaan Pendidikan. (Yogyakarta: Kaukaba, 2016), hlm. 27-28.
} 
Dari latar belakang tersebut pemerintah melalui Kementrian Agama mulai menggerakan Madrasah agar bisa dipercaya lebih oleh masyarakat dengan cara membuat program Madrasah yang lebih baik. Hal ini terbukti dengan adanya peran serta pemerintah untuk memajukan Madrasah dan animo masyarakat terhadap lembaga pendidikan Madrasah semakin hari semakin meningkat.

Perkembangan ini memberikan anginsegar bagi masyarkat muslim pada khususnya. Madrasah diharapkan mampu memainkan peranan dalam kehidupan yang mengalami perubahan.Pendidikan madrasah harus mampu membekali pengetahuan dan ketrampilan kepada peserta didik agar bisa menghadapi tantangan zaman. Hal ini akan terjadi jika dilaksanakan manjemen yang baik. Manajemen merupakan aspek yang mulai dilirik oleh para praktisi pendidikan agar institusi atau madrasah mengalami perkembangan yang signifikan.Pengukuran kinerja sekolah yang selama ini sering dilakukan adalah menggunakan perolehan nilai ujian nasional yang diukur rata rata ujian nasional saja.Model penilaian kinerja sekolah yang digunakan pemerintahadalah sistem penilaian kinerja dengan pola akreditasi sekolah yang dilaksanakan oleh BSNP.

Menurut PP No 19 Tahun 2005 secara internal sekolah diharapkan melakukan penilain kinerja dengan cara mengisi evaluasi diri sekolah (EDS). EDS merupakan evaluasi diri sekolah dalam pencapaian standar nasional pendidikan. Melalui EDS, sekolah dapat mengetahui data yang benar mulai standar isi, proses, sarana prasarana, kelulusan dll. EDS memberikan gambaran tentang pelaksanaan proses pendidikan di sekolah namun belum memberikan gambaran kinerja sekolah secara menyeluruh. ${ }^{2}$

Apabila membahas tentang mutu pendidikan maka tidak lepas dari kegiatan belajar mengajar.Kegiatan belajr mengajar di sekolah merupakan kegiatan yang paling fundamental. Ini berarti bahwa berhasil tidaknya pencapaian tujuan pendidikan antara lain bergantung pada bagaimana proses belajar yang dialami siswa sebagai peserta didik.

Menurut penelitian Wasty pengenalan seorang terhadap hasil belajar atau kemajuan belajarnya adalah penting. Karena dengan mengetahui hasil - hasil yang sudah dicapai maka siswa akan lebih berusaha meningkatkan hasil belajarnya, sehingga peningkatan hasil belajar dapat lebih optimal karena siswa tersebut merasa termotivasi untuk meningkatkan hasil belajar yang telah diraih sebelumnya. ${ }^{3}$

\footnotetext{
2 Depdiknas. Peraturan Pemerintah Nomor 19 Tahun 2005 tentang Standar Nasional Pendidikan. (Jakarta: Depdiknas, 2005).

${ }^{3}$ Wasty Soemanto. Psikologi Pendidikan: Landasan Kerja Pemimpin Pendidikan. (Cetakan ke-5). (Jakarta: Rineka Cipta, 2006).
} 
Hasil belajar yang diharapkan biasanya berupa prestasi belajar yang baik dan optimal,namun dalam pencapaian hasil belajar yang baik masih saja mengalami kesulitan dan prestasi yang didapat belum dicapai secara optimal.Dalam peningkatan hasil belajar siswa dipengaruhi oleh banyak faktor.Faktor yang mempengaruhi hasil belajar siswa diantaranya adalah motivasi, gaya belajar, dan suasana yang tercipta di sekolah.

Dalam upaya peningkatan kualitas pembelajaran berbagai upaya dapat dilakukan, yaitu dengan meningkatkan motivasi belajar dalam hal belajar siswa akan berhasil kalau dalam dirinya sendiri ada kemauan atau niat untuk mendapatkan hasil yang optimal. Selain itu, gaya belajar juga mempengaruhi hasil belajar siswa. Suasana belajar yang tercipta saat proses belajar mengajar di sekolah juga mempengaruhi kualitas pembelajaran. Apabila suasananya mendukung, maka proses pembelajaran juga akan lebih baik dan optimal.

MIN 3 Purworejo, Kabupaten Purworejo sebagai sekolah yang memiliki visi dan misi serta tujuan yang akan dicapai. Pencapaian tersebut sangat ditentukan oleh pengelola terhadap steakholder MIN 3 Purworejo, sejauh mana pencapaian visi, misi dan tujuan organisasi diperlukan penilaian kinerja sekolah agar kualitas pendidikan dan pengelola institusi pendidikan terus meningkat dan memberikan kepuasan terhadap seluruh steakholdernya.

Berdasarkan latar belakang tesebut, penulis bermaksud melakukan penelitian dengan judul Pengaruh Motivasi, Gaya Belajar, dan Suasana Religius Terhadap Prestasi Didik di MIN 3 Purworejo. Hal ini dilakukan dengan dasar masih minimnya peneliti untuk meningkatkan motivasi dan kegiatan keagamaan dengan suasana religius di sebuah madrasah pendidikan Islam.

\section{KAJIAN LITERATUR}

\section{Motivasi}

Menurut Mc. Donald yang dikutip oleh Sardiman, motivasi adalah perubahan energi dalam diri seseorang yang ditandai dengan munculnya "Feeling" dan didahului dengan tanggapan terhadap adanya tujuan. ${ }^{4}$ Sardiman menyatakan bahwa motivasi dapat juga dikatakan serangkaian usaha untuk menyediakan kondisi - kondisi tertentu, sehingga seseorang mau dan ingin melakukan sesuatu dan bila ia tidak suka, maka akan berusaha untuk meniadakan atau mengelakkan perasaan tidak suka itu. ${ }^{5}$ Jadi motivasi itu dapat

\footnotetext{
${ }^{4}$ A.M. Sardiman. Interaksi \& Motivasi Belajar Mengajar. (Jakarta: Rajawali Pers, 2012), hlm. 73.

${ }^{5} \mathrm{Ibid}, \mathrm{hlm} .75$.
} 
dirangsang oleh faktor dari luar tetapi motivasi itu tumbuh di dalam diri seseorang. Kesimpulan yang dapat diambil adalah motivasi tersebut akan tumbuk di dalam diri seseorang.

Hamzah B. Uno menyatakan bahwa motivasi adalah dorongan dasar yang menggerakkan seseorang bertingkah laku. ${ }^{6}$ Dorongan ini berada pada diri sendiri yang mengerakkan untuk melakukan sesuatu yang sesuai dengan dorongan dalam dirinya. Oleh karena itu, perbuatan seseorang yang didasarkan atas motivasi tertentu mengandung tema sesuai dengan motivasi yang mendasarinya.

Dari pengertian motivasi yang diuraikan di atas, dapat disimpulkan bahwa motivasi merupakan suatu usaha yang mendorong seseorang untuk bersaing dengan standar keunggulan, dimana standar keunggulan ini dapat berupa kesempurnaan tugas, dapat dari diri sendiri atau prestasi orang lain. Siswa yang mempunyai motivasi belajar tinggi maka nampaknya akan memperoleh prestai yang lebih tinggi pula dibandingkan dengan siswa lain yang kurang memiliki motivasi belajar. Sehingga perlu ditumbuhkan motivasi belajar yang tinggi disetiap individu supaya tujuan pembelajaran dapat tercapai secara maksimal.

Unsur - unsur motivasi belajar menurut Dimyati dan Mudjiono, ada beberapa faktor yang mempengaruhi motivasi belajar, yaitu: Cita - cita atau aspirasi siswa; Kemampuan belajar; Kondisi jasmani dan rohani siswa; Kondisi lingkungan kelas; Unsur - unsur dinamis belajar; dan Upaya guru mengajar siswa. ${ }^{7}$

Motivasi dapat dibedakan berdasarkan jenis - jenisnya, ada jenis motivasi yang timbul atau terjadi karena suatu keinginan seseorang untuk mendapatkan sesuatu. Sedangkan jenis motivasi yang lain yaitu motivasi yang terjadi karena seseorang tersebut ingin mencapai target yang telah ditentukan agar berhasil sesuai dengan apa yang diharapkan. Biggs dan Telfer menjelaskan bahwa jenis - jenis motivasi belajar dapat dibedakan menjadi empat macam, yaitu:

a. Motivasi instrumental, yaitu merupakan dorongan yang membuat peserta didik belajar karena ingin mendapatkan hadiah.

b. Motivasi sosial, yaitu motivasi yang menjadikan peserta didik lebih terlibat dalam suatu tugas yang diberikan.

c. Motivasi berprestasi, yaitu motivasi yang membuat peserta didik belajar untuk meraih keberhasilan yang telah ditentukan.

d. Motivasi instrinsik, yaitu motivasi yang membuat peserta didik memiliki rasa ingin belajar dengan keinginannya sendiri. ${ }^{8}$

\footnotetext{
${ }^{6}$ Hamzah B. Uno. Teori Motivasi dan Pengukurannya. (Jakarta: Bumi Aksara, 2012).

${ }^{7}$ Dimyati \& Mudjiono. Belajar dan Mengajar. (Jakarta: Rineka Cipta, 1994), hlm. 89-92.

${ }^{8}$ Sugihartono, dkk. Psikologi Pendidikan. (Yogyakarta: UNY Press, 2007), hlm. 78.
} 
Motivasi memiliki fungsi bagi seseorang, karena motivasi dapat menjadikan seseorang mengalami perubahan yang lebih baik. Oemar Hamalik menjelaskan fungsi motivasi, yaitu mendorong timbulnya kelakuan atau sesuatu perbuatan. ${ }^{9}$ Perbuatan belajar akan terjadi apabila seseorang tersebut memiliki motivasi, sebagai pengarah, artinya dapat menjadi jalan agar mampu menjuru arah yang ingin dicapai, sebagai penggerak, berfungsi sebagai mesin bagi mobil. Besar kecilnya motivasi akan menentukan cepat atau lambatnya suatu pekerjaan.

Berdasarkan fungsi motivasi di atas, maka dapat disimpulkan bahwa fungsi motivasi adalah memberikan arah dalam meraih apa yang diinginkan, menentukan sikap atau tingkah laku yang akan dilakukan untuk mendapatkan apa yang diinginkan dan juga sebagai alat pendorong seseorang untuk melakukan aktivitas.

\section{Gaya Belajar}

Setiap siswa memiliki cara yang berbeda dalam memahami dan menyerap suatu informasi yang didapatkan. Menurut Nasution, gaya belajar adalah gaya yang konsisten yang dilakukan oleh seorang murid dalam menangkap stimulus atau informasi, cara mengingat, berfikir dan memecahkan soal. ${ }^{10}$ Menurut Sternberg mendefinisikan gaya belajar sebagai suatu cara untuk menggunakan kemampuan seseorang. ${ }^{11}$

Tiap - tiap orang mempunyai kemampuan yang berbeda, sehingga cara yang digunakan pada saat belajar akan berbeda sesuai dengan kebutuhannya masing - masing. Menurut Rita dan Prashign menjelaskan bahwa gaya belajar sebagai suatu cara manusia mulai berkonsentrasi, menyerap, memproses, dan menampung informasi yang baru dan sulit. ${ }^{12}$ Gaya belajar digunakan dalam tiga proses belajar. Ketiga proses tersebut meliputi menyerap informasi baru, memproses informasi dan menampung informasi untuk kemudian menyimpannya. Jadi, gaya belajar akan digunakan dari proses awal menerimaan informasi sampai pengolahan informasi, sehingga menjadi informasi yang bermakna.

Berdasarkan paparan di atas, Penulis menyimpulkan, gaya belajar adalah suatu cara yang digunakan siswa pada saat belajar menangkap stimulus, menyerap, dan mengatur.

\footnotetext{
${ }^{9}$ Oemar Hamalik. Kurikulum dan Pembelajaran. (Jakarta: Bumi Aksara, 2011), hlm. 175.

${ }^{10}$ Nasution. Berbagai Pendekatan dalam Proses Belajar dan Mengajar. (Jakarta: Bumi Aksara, 2010), hlm. 9395.

${ }^{11}$ Paul Ginnis. Trik \& Taktik Mengajar - Strategi Meningkatkan Pencapaian Pengajaran di Kelas. (Jakarta: Indeks, 2008), hlm. 41.

${ }^{12}$ Mulyati. (2015). Jurnal Pembelajaran Gi, TPS, Kemandirian, Prestasi Belajar Matematika Siswa SMP Kelas VIII.
} 
Setiap orang memiliki kemampuan yang berbeda saat mengingat dan menginformasikan serta dapat memecahkan masalah dengan menggunakan kemampuan yang baik.

Gaya belajar tiap individu berbeda - beda, ada yang menyukai gambar, suara, praktek langsung, atau dengan mencatat kejadian yang terjadi. Menurut Deporter \& Henarcki, terdapat tiga gaya belajar seseorang, yaitu gaya belajar visual, auditorial, dan kinestetik. ${ }^{13}$ Walaupun masing - masing siswa belajar dengan menggunakan ketiga gaya belajar ini, kebanyakan siswa lebih cenderung pada salah satu diantara ketiga gaya tersebut.

\section{Suasana Religius}

Fetzer dalam Multidimensional Measurement of Religiousness, Spiritualityfor Use in Health Research mendefinisikan religiusitas ialah seberapa kuatindividu penganut agama merasakan pengalaman beragama sehari-hari (dailyspiritual experiences), mengalami kebermaknaan hidup dalam beragama (religion meaning), mengekspresikan keagamaan sebagai sebuah nilai (values), meyakiniajaran agamanya (beliefs), memaafkan (forgiveness), melakukan praktik keagamaan (ibadah) secara menyendiri (private religious practicess), menggunakan agama sebagai (religious/spiritual coping), mendapat dukungan penganut sesama agama (religious support), mengalami sejarah keberagamaan (religious/spiritual history), komitmen beragama (commitment), mengikuti organisasi/kegiatan keagamaan (organizational religiousness) dan meyakini pilihan agamanya (religious preference). ${ }^{14}$ Seorang dapat dikatakan religius apabila memiliki ciriciri dari dua belas dimensi religiusitas tersebut.Jadi, dapat dikatakan bahwa religiusitas seseorang dapat dilihat dari seberapa kuat penghayatan dan pemahaman terhadap agama melalui dimensi-dimensi religiusitas yang telah disebutkan.

Sedangkan Thouless mendefinisikan Religion adalah sikap atau cara penyesuaian diri terhadap dunia yang mencakup acuan yang menunjukkan lingkungan yang lebih luas dari pada lingkungan dunia fisik yang terikat ruang dan waktu. ${ }^{15}$ Berkaitan dengan religiusitas Islam, kualitas religiusitas seseorang ditentukan oleh seberapa jauh individu memahami, menghayati, dan mengamalkan ajaran-ajaran serta perintah Allah secara kaffah atau menyeluruhdan optimal.Untuk mengukur religiusitas tersebut, dikenal tiga

\footnotetext{
${ }^{13}$ Dirman \& Juarsih. Penilaian dan Evaluasi. (Jakarta: Rineka Cipta, 2014), hlm. 100-102.

${ }^{14}$ John E. Fetzer. Multidimentional Measurement of Religiousness / Spirituality for Use in Health. (Kalamazo: John E. Fetzer Institute, 1999).

15 Robert H. Thouless. Pengantar Psikologi Agama. Terjemahan Machnun Husein. (Jakarta: Raja Grafindo Persada, 1992).
} 
dimensi dalam Islam yaitu aspek aqidah (keyakinan), syari'ah (praktik agama, ritual formal) dan akhlak (pengamalan dari aqidah dan syari'ah).

Dari penjelasan di atas dapat disimpulkan bahwa religiusitas adalah keyakinan, penghayatan, pengalaman, pengetahuan, dan peribadatan penganut agama terhadap agamanya yang diaplikasikan dalam kehidupannya sehari-hari sebagai pengakuan akan adanya kekuatan tertinggi yang menaungi kehidupan manusia di dunia dan akhirat.

Dalam penelitian yang dilakukan oleh John E. Fetzer Institute yang berjudul Multidimensional Measurement of Religiousness, Spirituality for Use in Health Research dikemukakan religiusitas meliputi dua belas dimensi yaitu:

a. Daily spiritual experiences merupakan dimensi yang memandang dampakagama dan spritual dalam kehidupan sehari-hari. Dalam hal ini daily spiritualexperinces merupakan persepsi individu terhadap sesuatu yang berkaitandengan transenden dalam kehidupan sehari-hari dan persepsi terhadap interaksinya pada kehidupan tersebut, sehingga daily spiritual experinces lebih kepada pengalaman dibandingkan kognitif.

b. Adapun meaning dijelaskan oleh Pragment bahwa, konsep meaning dalam religiusitas sebagaimana konsep meaning yang dijelaskan oleh Fiktor Vrankl yang biasa disebut dengan istilah kebermaknaan hidup. Adapun meaning yang dimaksud di sini adalah yang berkaitan dengan religiusitas atau disebut religion-meaning yaitu sejauh mana agama dapat menjadi tujuan hidupnya.

c. Konsep value menurut Idler ialah pengaruh keimanan terhadap nilai-nilahidup, seperti mengajarkan tentang nilai cinta, saling tolong, saling melindungi, dan sebagainya.

d. Konsep belief menurut Idler merupakan sentral dari religiusitas. Religiusitas merupakan keyakinan akan konsep-konsep yang dibawa oleh suatu agama.

e. Dimensi forgiveness menurut Idler mencakup lima dimensi turunan, yaitu:

1) Pengakuan dosa (confession).

2) Merasa diampuni oleh Tuhan (feeling forgiven by God).

3) Merasa dimaafkan oleh orang lain (feeling forgiven by others).

4) Memaafkan orang lain (forgiving others).

5) Memaafkan diri sendiri (forgiving one self)

Namun posisi dimensi forgiving others tidak sama dengan forgiveness sebagai dependen variabel. Dimensi forgiving others pada dimensi religiusitas yang 
dimaksud adalah sikap memaafkan yang lebih terkait dengan keberagamaan, motivasi memaafkan lebih pada motivasi mengharapkan pahala dan menjauhkan dosa karena membalas dendam merupakan perbuatan tercela dan memaafkan adalah anjuran dalam agama.

f. Private religious practices menurut Levin merupakan perilaku beragamadalampraktek agama meliputi ibadah, mempelajari kitab, dan kegiatankegiatan lain untuk meningkatkan religiusitasnya.

g. Religious/spiritual coping menurut Pragament merupakan coping stress denganmenggunakan pola dan metode religius. Seperti dengan berdoa, beribadah untuk menghilangkan stres, dan sebagainya. MenurutPragment(1988) yang menjelaskan bahwa ada tiga jenis coping secara religius, yaitu:

1) Deferring style, yaitu memeinta penyelesaian masalah kepada Tuhan saja.Yaitu dengan cara berdoa dan meyakini bahwa Tuhan akan menolong hamba-Nya dan menyerahkan semuanya kepada Tuhan.

2) Colaborative style, yaitu hamba meminta solusi kepada Tuhan danhambanya senantiasa berusaha untuk melakukan coping.

3) Self-directing style, yaitu individu bertanggung jawab sendiri dalammenjalankan coping.

h. Konsep religous support menurut Krause adalah aspek hubungan sosial antaraindividu dengan pemeluk agama sesamanya. Dalam Islam hal semacam ini sering disebut al-Ukhuwah al-Islamiyah.

i. Konsep religious/spiritual history menurut George adalah seberapa jauhindividu berpartisipasi untuk agamanya selama hidupnya dan seberapa jauh agama memepngaruhi perjalanan hidupnya.

j. Konsep commitment menurut Williams adalah seberapa jauh individumementingkan agamanya, komitmen, serta berkontribusi kepadaagamanya.

k. Konsep organizational religiousness menurut Idler merupakan konsepyang mengukur seberapa jauh individu ikut serta dalam lembagakeagamaan yang ada di masyarakat dan beraktifitas di dalamnya.

1. Konsep religious preference menurut Ellison yaitu memandang sejauh mana individu membuat pilihan dan memastikan pilihan agamanya. ${ }^{16}$

${ }^{16}$ John E. Fetzer, Op.Cit. 
Dari 12 dimensi di atas yang diikut sertakan sebagai dimensi dalam penelitian ini hanya 5 dimensi, diantaranya: (a) daily spiritual experience, (b) religion-meaning, (c) private religious practice, (d) religious/spiritual coping, dan (e) religious support. Dimensi yang tidak diikutsertakan dalam variabel religiusitasdalam penelitian ini ialah: value, belief, forgiveness, commitment,religious/spiritual histrory, organizational religiousness, religious preference. Dimensi-dimensi ini tidak diikut sertakan dalam penelitian dikarenakan memiliki kesamaan makna dengan dimesi dari varibel kecerdasan moral, dengan maksud untuk menghindari makna yang tumpang tindih dari dimensi kedua independentvariable, maka dimensi yang memiliki makna yang sama tidak diikutsertakandalam penelitian. Dan yang terakhir dimensi pilihan agama (religious preference) juga tidak dicantumkan dalam instrumen penelitian ini, dengan alasan responden penelitian merupakan siswa yang menganut paham agama semenjak lahir dan mengikuti agama yang dianut orang tuanya, dengan demikian, dimensi pilihan agama (religious preference) tidak diikut sertakan dalam penelitian.

Religiusitas diukur dengan menggunakan skala religiusitas berdasarkan teori Fetzer dengan menggunakan dua belas aspek yaitu: (a). daily spiritual experience; (b). religionmeaning; (c). value; (d). belief; (e). forgiveness; (f).private religious practice; (g). religious/ spiritual coping; (h). religious/ spiritual history; (i). commitment; (j). organizational religious; (k). religious preference; dan (1). religious preference. ${ }^{17}$

\section{Prestasi Belajar Peserta Didik}

Kata prestasi belajar berasal dari bahahsa Belanda "prestatile" kemudian dalam bahasa Indonesia diserap menjadi "prestasi" yang berarti hasil usaha. Kata ini banyak digunakan dalam berbagai bidang kegiatan lain, seperti olahraga, kesenian, serta pendidikan. Setiap jangka waktu tertentu, lembaga pendidikan akan mengadakan suatu tes untuk mengetahui tingkat penyerapan siswa terhadap bbahan pelajaran yang telah diberikan. Berdasarkan hasil tersebut, selanjutnya guru mengadakan penilaian terhadap prestasi yang dicapai oleh siswa dalam proses pembelajarannya.

Menurut Susanto, prestasi belajar adalah tingkat keberhasilan siswa dalam mempelajari materi pelajaran di sekolah yang dinyatakan dalam skor yang diperoleh dari hasil tes mengenai sejumlah materi pelajaran tertentu. ${ }^{18}$ Selanjutnya, Niken Ariani dan Dany Haryanto

\footnotetext{
17 Ibid.

${ }^{18}$ Ahmad Susanto. Teori Belajar dan Pembelajaran di Sekolah Dasar. (Jakarta: Kencana Prenada Media Group, 2013), hlm. 5.
} 
mengemukakan bahwa, prestasi belajar adalah hasil usaha bekerja atau belajar yang menunjukkan ukuran kecakapan yang dicapai dalam bentuk nilai. Sedangkan nilai - nilai tersebut sebagai ukuran kecakapan dari usaha belaar yang telah dicapai seseorang, prestasi belajar ditunjukkan dengan jumlah nilai raport atau tes nilai sumatif. ${ }^{19}$ Menurut Masidjo, kegiaan pengukuran prestasi belajar siswa dari suatu mata pelajaran dilakukan antara lain rapor atau nilai - nilai test sumatif. ${ }^{20}$

Dari beberapa pengertian di atas, maka dapat disimpulkan bahwa Prestasi belajar peserta didik adalah seperangkat kemampuan (kognitif, psikomotorik, afektif) yang dimiliki peserta didik setelah mengikuti proses pembelajaran. Prestasi belajar peserta didik sebagai ukuran tingkat keberhasilan seorang siswa merupakan suatu konsep bentuk dari dua suku kata yang tingkat keberhasilannya ditentukan oleh berbagai faktor. Prestasi peserta didik dipengaruhi oleh banyak faktor, seperti kepemimpinan kepala sekolah, kinerja guru, dan media pembelajaran. Prestasi belajar peserta didik yang dimaksud dalam penelitian ini yaitu prestasi akademik, dalam hal ini diukur dari nilai raport pada tahun terakhir.

\section{METODE PENELITIAN}

Penelitian ini menggunakan pendekatan kuantitatif korelasional. Waktu penelitian adalah antara bulan Februari sampai dengan bulan Agustus 2019, dan tempat penelitian adalah di MIN 3 Purworejo. Dalam penelitian ini populasinya adalah seluruh peserta didik di MIN 3 Purworejo. Sedangkan sampelnya Peserta didik kelas VI di MIN 3 Purworejo yang berjumlah 40 orang.

Teknik pengumpulan data menggunakan teknik kuisioner atau angket yang berisi sejumlah pertanyaan tertulis yang digunakan untuk memperoleh informasi dari responden, yaitu mengenai: motivasi, gaya belajar, suasana religius, dan prestasi belajar peserta didik. Sedangkan penyusunan instrumen dalam penelitian ini dilakukan dengan beberapa tahapan, yaitu: (1) menentukan variabel penelitian; (2) menyusun indikator variabel penelitian; (3) menyusun kisi-kisi instrumen; (4) melakukan uji coba instrumen; dan (5) melakukan pengujian validitas dan reliabilitas instrumen.

Sebelum melakukan analisis data, terlebih dahulu dilakukan uji persyaratan analisis yaitu pengujian linearitas data, normalitas data, autokorelasi data, dan multikolinieritas data,

\footnotetext{
${ }^{19}$ Niken Ariani \& Dany Haryanto. Pembelajaran Multimedia di Sekolah. (Jakarta: Prestasi Pustaka, 2010), hlm. 10 .

${ }^{20}$ Masidjo. Penilaian Pencapaian Hasil Belajar Siswa di Sekolah. (Yogyakarta: Kanisius, 1995), hlm. 13.
} 
serta heterokedastisitas. Selanjutnya, dilakukan analisis regresi sederhana dan analisis regresi ganda.

\section{HASIL PENELITIAN DAN PEMBAHASAN}

\section{Pengaruh Motivasi terhadap Prestasi Belajar Peserta Didik di MIN 3 Purworejo}

Motivasi (X1), merupakan suatu usaha yang mendorong seseorang untuk bersaing dengan standar keunggulan, dimana standar keunggulan ini dapat berupa kesempurnaan tugas, dapat dari diri sendiri atau prestasi orang lain. Siswa yang mempunyai motivasi belajar tinggi maka nampaknya akan memperoleh prestai yang lebih tinggi pula dibandingkan dengan siswa lain yang kurang memiliki motivasi belajar. Fungsi motivasi adalah memberikan arah dalam meraih apa yang diinginkan, menentukan sikap atau tingkah laku yang akan dilakukan untuk mendapatkan apa yang diinginkan dan juga sebagai alat pendorong seseorang untuk melakukan aktivitas.

Ngalim Purwanto berpendapat, bahwa setiap motif itu berkaitan erat dengan suatu tujuan dan cita - cita. Makin berharga tujuan itu bagi yang bersangkutan, makin kuat pula motifnya sehingga motif itu sangat berguna bagi tindakan atau perbuatan seseorang. ${ }^{21}$ Hamzah B. Uno menyatakan bahwa motivasi adalah dorongan dasar yang menggerakkan seseorang bertingkah laku, dorongan ini berada pada diri sendiri yang mengerakkan untuk melakukan sesuatu yang sesuai dengan dorongan dalam dirinya. ${ }^{22}$ Oleh karena itu, perbuatan seseorang yang didasarkan atas motivasi tertentu mengandung tema sesuai dengan motivasi yang mendasarinya.

Motivasi memiliki fungsi bagi seseorang, karena motivasi dapat menjadikan seseorang mengalami perubahan yang lebih baik.Motivasi juga dapat mendorong seseorang untuk melakukan sesuatu. Oemar Hamalik menjelaskan fungsi motivasi, yaitu mendorong timbulnya kelakuan atau sesuatu perbuatan. Perbuatan belajar akan terjadi apabila seseorang tersebut memiliki motivasi, sebagai pengarah, artinya dapat menjadi jalan agar mampu menjuru arah yang ingin dicapai, sebagai penggerak, berfungsi sebagai mesin bagi mobil.

\footnotetext{
${ }^{21}$ Ngalim Purwanto. Psikologi Pendidikan. (Bandung: Rosda Karya, 2010), hlm. 70-71.

${ }^{22}$ Hamzah B. Uno, Op.Cit.
} 
Besar kecilnya motivasi akan menentukan cepat atau lambatnya suatu pekerjaan/prestasi belajar peserta didik. ${ }^{23}$

Hasil analisis menunjukkan bahwa motivasi memiliki korelasi yang cukup positif dengan prestasi belajar peserta didik di MIN 3 Purworejo. Hal tersebut terbukti dari nilai $r$ sebesar 0,329. Positif artinya searah, maksudnya semakin tinggi motivasi, maka semakin tinggi prestasi belajar peserta didik. Selanjutnya, untuk menguji apakah satu variabel independen $\left(\mathrm{X}_{1}\right)$ secara parsial mempunyai pengaruh terhadap variabel dependen $(\mathrm{Y})$, maka digunakan Uji t. Berdasarkan hasil analisis, diketahui bahwa nilai Sig $=0,038<\alpha=0,05$, maka Ho ditolak dan Ha diterima. Dengan demikian, hipotesis pertama yang dinyatakan "Motivasiberpengaruh secarasignifikan terhadap Prestasi Belajar Peserta Didik di MIN 3 Purworejo" adalah terbukti kebenarannya. Adapun $\mathrm{r}^{2}$ ( $\mathrm{r}$ square atau korelasi koefisien) $=0,108$, atau menunjukkan bahwa $\mathrm{X}_{1}$ berkontribusi sebesar $10,8 \%$ terhadap $\mathrm{Y}$.

\section{Pengaruh Gaya Belajar terhadap Prestasi Belajar Peserta Didik di MIN 3 Purworejo}

Gaya Belajar (X2), adalah suatu cara yang digunakan siswa pada saat belajar menangkap stimulus, menyerap, dan mengatur. Gaya belajar akan digunakan dari proses awal menerimaan informasi sampai pengolahan informasi, sehingga menjadi informasi yang bermakna. Jenis - jenis gaya belajar ada tiga, yaitu belajar dengan cara melihat (visual), belajar dengan cara mendengar (auditif), dan belajar dengan cara bergerak, bekerja, menyentuh (kinestetik).

Tiap - tiap orang mempunyai kemampuan yang berbeda, sehingga cara yang digunakan pada saat belajar akan berbeda sesuai dengan kebutuhannya masing - masing. Menurut Rita dan Prashign menjelaskan bahwa gaya belajar sebagai suatu cara manusia mulai berkonsentrasi, menyerap, memproses, dan menampung informasi yang baru dan sulit. Gaya belajar digunakan dalam tiga proses belajar. Ketiga proses tersebut meliputi menyerap informasi baru, memproses informasi dan menampung informasi untuk kemudian menyimpannya. ${ }^{24}$ Jadi, gaya belajar akan digunakan dari proses awal menerimaan informasi sampai pengolahan informasi, sehingga menjadi informasi yang bermakna.

Menurut Deporter dan Henarcki terdapat tiga gaya belajar seseorang, yaitu gaya belajar visual, auditorial, dan kinestetik. $^{25}$ Walaupun masing - masing siswa belajar dengan

\footnotetext{
${ }^{23}$ Oemar Hamalik, Op.Cit.

${ }^{24}$ Mulyati, Op.Cit.

${ }^{25}$ Dirman \& uarsih, Op.Cit.
} 
menggunakan ketiga gaya belajar ini, kebanyakan siswa lebih cenderung pada salah satu diantara ketiga gaya tersebut.

Hasil analisis menunjukkan bahwa gaya belajarmemiliki korelasi yang cukup positif dengan prestasi belajar peserta didik di MIN 3 Purworejo. Hal tersebut terbukti dari nilai $r$ sebesar 0,375 . Positif artinya searah, maksudnya semakin tinggi gaya belajar, maka semakin tinggi prestasi belajar peserta didik. Selanjutnya, untuk menguji apakah satu variabel independen $\left(\mathrm{X}_{2}\right)$ secara parsial mempunyai pengaruh terhadap variabel dependen $(\mathrm{Y})$, maka digunakan Uji t. Berdasarkan hasil analisis, diketahui bahwa nilai Sig $=0,017<\alpha=0,05$, maka Ho ditolak dan Ha diterima. Dengan demikian, hipotesis kedua yang dinyatakan "Gaya Belajar berpengaruh secara signifikaan terhadap Prestasi Belajar Peserta Didik di MIN 3 Purworejo" adalah terbukti kebenarannya. Adapun $\mathrm{r}^{2}$ ( $\mathrm{r}$ square atau korelasi koefisien) $=$ 0,141, atau menunjukkan bahwa $\mathrm{X}_{1}$ berkontribusi sebesar $14,1 \%$ terhadap $\mathrm{Y}$.

\section{Pengaruh Suasana Religius terhadap Prestasi Belajar Peserta Didik di MIN 3 Purworejo}

Suasana Religius (X3), adalah suasana yang diliputi oleh nilai-nilai spiritual. Suasana yang penuh keyakinan, penghayatan, pengalaman, pengetahuan, dan peribadatan penganut agama terhadap agamanya yang diaplikasikan dalam kehidupannya sehari-hari sebagai pengakuan akan adanya kekuatan tertinggi yang menaungi kehidupan manusia di dunia dan akhirat.

Fetzer dalam Multidimensional Measurement of Religiousness, Spiritualityfor Use in Health Research mendefinisikan religiusitas ialah seberapa kuat individu penganut agama merasakan pengalaman beragama sehari-hari (dailyspiritual experiences), mengalami kebermaknaan hidup dalam beragama (religion meaning), mengekspresikan keagamaan sebagai sebuah nilai (values), meyakini ajaran agamanya (beliefs), memaafkan (forgiveness), melakukan praktik keagamaan (ibadah) secara menyendiri (private religious practicess), menggunakan agama sebagai (religious/spiritual coping), mendapat dukungan penganut sesama agama (religious support), mengalami sejarah keberagamaan (religious/spiritual history), komitmen beragama (commitment), mengikuti organisasi/kegiatan keagamaan (organizational religiousness) dan meyakini pilihan agamanya (religious preference). ${ }^{26}$ Seorang dapat dikatakan religius apabila memiliki ciriciri dari dua belas dimensi religiusitas tersebut. Jadi, dapat dikatakan bahwa religiusitas

\footnotetext{
${ }^{26}$ John E. Fetzer, Op.Cit.
} 
seseorang dapat dilihat dari seberapa kuat penghayatan dan pemahaman terhadap agama melalui dimensi-dimensi religiusitas yang telah disebutkan.

Berkaitan dengan religiusitas Islam, kualitas religiusitas seseorang ditentukan oleh seberapa jauh individu memahami, menghayati, dan mengamalkan ajaran-ajaran serta perintah Allah secara kaffah atau menyeluruh dan optimal. Untuk mengukur religiusitas tersebut, dikenal tiga dimensi dalam Islam yaitu aspek aqidah (keyakinan), syari'ah (praktik agama, ritual formal) dan akhlak (pengamalan dari aqidah dan syari'ah). Melalui suasana religius diharapkan mampu memupuuk semangat belajar, sehingga prestasi peserta didik meningkat.

Hasil analisis menunjukkan bahwa suasana religiusmemiliki korelasi yang sangat lemah positif dengan prestasi belajar peserta didik. Hal tersebut terbukti dari nilai $\mathrm{r}$ sebesar 0,008. Positif artinya searah, maksudnya semakin tinggi suasana religius, maka semakin tinggi prestasi belajar peserta didik. Selanjutnya, untuk menguji apakah satu variabel independen $\left(\mathrm{X}_{1}\right)$ secara parsial mempunyai pengaruh terhadap variabel dependen $(\mathrm{Y})$, maka digunakan Uji t. Berdasarkan hasil analisis, diketahui bahwa nilai $\mathrm{Sig}=0,000<\alpha=0,05$, maka Ho ditolak dan Ha diterima. Dengan demikian, hipotesis ketiga yang dinyatakan "Suasana Religius berpengaruh secara signifikan terhadap Prestasi Belajar Peserta Didik di MIN 3 Purworejo" adalah tidak terbukti kebenarannya. Adapun $r^{2}(r$ square atau korelasi koefisien $)=0,000$, atau menunjukkan bahwa $\mathrm{X}_{1}$ berkontribusi sebesar $00,0 \%$ terhadap $\mathrm{Y}$.

\section{Pengaruh Moivasi, Gaya Belajar, dan Suasana Religius Secara Bersama-sama terhadap Prestasi Belajar Peserta Didik di MIN 3 Purworejo}

Prestasi Belajar Peserta Didik (Y),adalah seperangkat kemampuan (kognitif, psikomotorik, afektif) yang dimiliki peserta didik setelah mengikuti proses pembelajaran. Prestasi belajar peserta didik yang dimaksud dalam penelitian ini yaitu prestasi akademik atau hasil belajar peserta didik, dalam hal ini diukur dari nilai raport pada tahun terakhir.

Motivasi, gaya belajar, dan suasana religius secara bersama-sama memiliki korelasi yang cukup positif dengan kinerja guru. Hal tersebut terbukti dari nilai $\mathrm{R}$ sebesar 0,445. Positif artinya searah, maksudnya semakin tinggi motivasi, gaya belajar, dan suasana religius, maka semakin tinggi prestasi belajar peserta didik. Selanjutnya, untuk menguji apakah semua variabel independen $\left(\mathrm{X}_{1}, \mathrm{X}_{2}, \mathrm{X}_{3}\right)$ mempunyai pengaruh secara bersama-sama atau pengaruh secara simultan terhadap variabel dependen (Y), maka digunakan Uji $F$.

Berdasarkan hasil Uji F, diketahui bahwa $\mathrm{F}_{\text {hitung }}=29,69>\mathrm{F}_{\text {tabel }}=4,08$, maka Ho ditolak dan Ha diterima. Selanjutnya, nilai Sig $=0,045<\alpha=0,05$, maka Ho ditolak dan Ha 
diterima. Dengan demikian, hipotesis keempat yang dinyatakan "Motivasi, Gaya Belajar, dan Suasana Religius secara Bersama-sama Berpengaruh secara signifikan terhadap Prestasi Belajar Peserta Didik di MIN 3 Purworejo" adalah terbukti kebenarannya. Adapun $\mathrm{R}^{2}$ (r square atau korelasi koefisien) $=0,198$, atau menunjukkan bahwa $\mathrm{X}_{1}, \mathrm{X}_{2}, \mathrm{X}_{3}$ secara bersamasama berkontribusi sebesar $19,8 \%$ terhadap Y.

\section{KESIMPULAN}

Berdasarkan hasil penelitian dan pembahasan yang telah dipaparkan dalam bab sebelumnya, maka dapat diangkat simpulan sebagai berikut:

1. Motivasimemiliki pengaruh yang cukuppositif terhadapPrestasi Belajar Peserta Didik di MIN 3 Purworejo, terbuktidarinilai Sig $=0,038<\alpha=0,05$. Adapun nilai koefisien korelasi $\left(\mathrm{r}^{2}\right)=0,108$ atauberkontribusisebesar10,8\%.

2. Gaya Belajar memiliki pengaruh yang cukup positif terhadap Prestasi Belajar Peserta Didik di MIN 3 Purworejo, terbuktidarinilai Sig $=0,017<\alpha=0,05$. Adapun nilai koefisien korelasi $\left(\mathrm{r}^{2}\right)=0,141$ atau berkontribusi sebesar $14,1 \%$.

3. Suasana Religius memiliki pengaruh yang lemah positif terhadap Prestasi Belajar Peserta Didik di MIN 3 Purworejo, terbuktidarinilai Sig $=0,000<\alpha=0,05$. Adapun nilai koefisien korelasi $\left(\mathrm{r}^{2}\right)=0,000$ atau berkontribusi sebesar $00,0 \%$.

4. Motivasi, Gaya Belajar, dan Suasana Religius Secara Bersama-sama memiliki pengaruh yang cukup positif terhadap Prestasi Belajar Peserta Didik di MIN 3 Purworejo,terbukti dari nilai Sig $=0,045<\alpha=0,05$. Adapun nilai koefisien korelasi $\left(\mathrm{R}^{2}\right)=0,198$ atau berkontribusi sebesar $19,8 \%$.

\section{DAFTAR PUSTAKA}

Ahmad Susanto. (2013). Teori Belajar dan Pembelajaran di Sekolah Dasar. Jakarta: Kencana Prenada Media Group.

A.M. Sardiman. (2012). Interaksi \& Motivasi Belajar Mengajar. Jakarta: Rajawali Pers.

Depdiknas. (2005). Peraturan Pemerintah Nomor 19 Tahun 2005 tentang Standar Nasional Pendidikan. Jakarta: Depdiknas.

Dimyati \& Mudjiono. (1994). Belajar dan Mengajar. Jakarta: Rineka Cipta.

Dirman \& Juarsih. (2014). Penilaian dan Evaluasi. Jakarta: Rineka Cipta.

Hamzah B. Uno. (2012). Teori Motivasi dan Pengukurannya. Jakarta: Bumi Aksara.

Imam Machali \& Ara Hidayat. (2016). Pengelolaan Pendidikan. Yogyakarta: Kaukaba. 
John E. Fetzer. (1999). Multidimentional Measurement of Religiousness / Spirituality for Use in Health. Kalamazo: John E. Fetzer Institute.

Masidjo. (1995). Penilaian Pencapaian Hasil Belajar Siswa di Sekolah. Yogyakarta: Kanisius.

Mulyati. (2015). Jurnal Pembelajaran Gi, TPS, Kemandirian, Prestasi Belajar Matematika Siswa SMP Kelas VIII.

Nasution. (2010). Berbagai Pendekatan dalam Proses Belajar dan Mengajar. Jakarta: Bumi Aksara.

Ngalim Purwanto (1992). Psikologi Pendidikan. Bandung: Rosda Karya.

Niken Ariani \& Dany Haryanto. (2010). Pembelajaran Multimedia di Sekolah. Jakarta: Prestasi Pustaka.

Oemar Hamalik. (2011). Kurikulum dan Pembelajaran. Jakarta: Bumi Aksara.

Paul Ginnis. (2008). Trik \& Taktik Mengajar - Strategi Meningkatkan Pencapaian Pengajaran di Kelas. Jakarta: Indeks.

Robert H. Thouless. (1992). Pengantar Psikologi Agama. Terjemahan Machnun Husein. Jakarta: Raja Grafindo Persada.

Sugihartono, dkk. (2007). Psikologi Pendidikan. Yogyakarta: UNY Press.

Wasty Soemanto. (2006). Psikologi Pendidikan: Landasan Kerja Pemimpin Pendidikan. (Cetakan ke-5). Jakarta: Rineka Cipta. 